\title{
THE EFFECT SELF-EFFICACY AND SOCIAL SUPPORT ON WORK STRESS OF TEACHERS
}

\author{
P-ISSN: 2089-4341 | E-ISSN: 2655-9633 \\ https://uia.e-journal.id/akademika/article/view/1112 \\ DOI: 10.34005/akademika.v9i02.1112
}

Submitted: 2020-11-5 Reviewed: 2020-11-23 Published: 2020-11-30

\author{
Masduki Ahmad \\ masduki@unj.ac.id \\ State University of Jakarta
}

\begin{abstract}
This study aims to analyze the effects of self-efficacy and social support on work stress for civil servant teachers at Elementary School in Pondok Kelapa Village. This study uses multiple linear regression models as the main analysis tool. This study used a sample of 81 civil servant teachers at Elementary School in Pondok Kelapa Village. The research instrument was a closed questionnaire using a Likert scale and was applied via a google form. Statistical calculations in this study were carried out using SPSS version 25. To test the hypothesis, it was carried out $u$ using the $t$-test and the $F$ test. From the research that has been conducted, it has in several conclusions including: 1) Self-efficacy has a negative and significant effect on work stress for civil servant teachers at Elementary School in Pondok Kelapa Village, that mean the higher the self-efficacy, the lower the work stress; 2) Social support has a negative and significant effect on the work stress of civil servant teachers at Elementary School in Pondok Kelapa Village, meaning that the higher social support, the lower the work stress 3) Self-efficacy and social support have a significant effect on the work stress of civil servant teachers at Elementary School in Pondok Kelapa Village with a coefficient of determination of 0.597 or $59.7 \%$, which means that self-efficacy and social support affect work stress by $59.7 \%$, while the other $40.3 \%$ are influenced by other factors not examined.
\end{abstract}

Keywords: Self- Efficacy, Social Support, Work Stress

\begin{abstract}
Abstark: Penelitian ini bertujuan untuk menganalisis pengaruh efikasi diri dan dukungan sosial terhadap stres kerja pada guru PNS Sekolah Dasar di Kelurahan Pondok Kelapa. Penelitian ini menggunakan model regresi linier berganda sebagai alat analisis utama. Penelitian ini menggunakan sampel 81 guru PNS Sekolah Dasar di Kelurahan Pondok Kelapa. Instrumen penelitian berupa angket tertutup dengan skala likert dan diaplikasikan melalui google form. Perhitungan statistik dalam penelitian ini dilakukan dengan menggunakan SPSS versi 25. Untuk menguji hipotesis dilakukan dengan menggunakan uji-t dan uji F. Dari penelitian yang telah dilakukan diperoleh beberapa kesimpulan diantaranya 1) Self-efficacy berpengaruh negatif dan signifikan terhadap stres kerja pada guru PNS Sekolah Dasar di Kelurahan Pondok Kelapa, dengan nilai signifikansi 0,000 ( $\alpha<0,005)$.); 2) Dukungan sosial berpengaruh negatif dan signifikan terhadap stres kerja guru PNS SD di Kelurahan Pondok Kelapa, dengan nilai signifikansi 0,000 ( $\alpha<0,005)$ dan 3) Efikasi diri dan dukungan sosial berpengaruh signifikan terhadap stres kerja guru PNS Sekolah Dasar di Desa Pondok Kelapa dengan nilai signifikansi 0,000 $(\alpha<0,005)$ dan koefisien determinasi 0,597 atau 59,7\%.
\end{abstract}

177 | Akademika | Vol 9 | No. 2 | 2020 
Keywords: Efikasi Diri, Dukungan Sosial, Stres Kerja

\section{INTRODUCTION}

School as a place to take education is strongly influenced by the elements that support it. One of the important elements is the teacher. The teacher is one of the factors that determine whether or not the goals of education in school are achieved. Schools as education delivery units certainly have to pay close attention to teacher performance if they want maximum results and output. Teachers who have good performance will certainly produce quality learning for students. However, it is not uncommon for teachers to experience various problems in their work as educators.

One of the problems that teachers often face is job stress. The work stress experienced by teachers is related to their situation in facing their working conditions as an educator. Teachers often have high demands for performance as well as a great responsibility and extraordinary expectations from parents of students, causing work stress on teachers (Wahdaniyah \& Miftahuddin, 2019). This condition causes work stress on teachers to increase. This problem usually will continue because the teacher does not have the ability and awareness to cope with this stress. Most teachers do not yet have adequate knowledge about the importance of managing stress and they even consider this problem to be resolved by itself (Putranto, 2013). With the increase in work stress, it will certainly affect the performance of teachers in schools.

Job stress is a transaction of sources of work stress with one's own capacity, which results in a positive or negative response ("Work Stress," 2015). Job stress is a response to what he faced at work. As previously stated, stress occurs when there are triggering factors such as excessive workload or working time that exceed capacity. Job stress can also be defined as a person's interaction with their work environment and also the person's awareness of their inability to cope with environmental demands (Yana, 2014). Job stress is also related to individual responses in adjusting to working situations and events that give them psychological and physical demands when carrying out their jobs (Paramita \& Sendow, 2016). From some of the previous descriptions, it can be concluded that job stress is a person's response to job demands that affect their physical and psychological effects which later have a positive or negative impact on their work performance.

A teacher is a profession that often experiences job stress. Job stress is a concern because of its immediate impact on one's performance. Someone who experiences work stress will usually produce a response that can be seen. The response can be either a positive response which eventually will improve their performance, or the response that can 
also be a negative response in which their performance will drop significantly. Excessive stress levels will cause employees to be depressed because they are no longer able to handle tasks that are too heavy (Wartono, 2017). Teachers as a profession are required to face various responsibilities and people are, of course, very vulnerable to work stress. The responsibility of teachers who are not only providing learning in the classroom but also having to complete other responsibilities such as preparing lesson plans to be used, attending training, or attending school activities, will cause the teacher to feel that his workload is too much, causing the teacher to experience work stress. In addition, job stress affects not only performance but also the health of the individuals who experience it (Triana et al., 2015).

The work stress of the teacher is actually also influenced by other factors such as self-efficacy or self-efficacy. Self-efficacy is described as the level of a person's ability to convince himself to face problems in order to avoid work stress (Steven \& Sahrah, 2019). This means that someone who has high self-efficacy will be able to avoid work stress. In this case, teachers who have high self-efficacy in their work are less likely to experience work stress. Kusnadi delivers something similar that someone who has self-efficacy or confidence is low, tends to lead to less rather they determine attitudes, such as decision-making and how to do his job well, where if the situation comes up then the stress of work will be created (Kusnadi, 2014). When the teacher feels insecure, he will not be able to determine what actions to take when facing his job, which will also lead to work stress. In addition, self-efficacy also affects many aspects of our lives, including the potential to deal with stressor, in dealing with new environments and work performance (Efendi, 2013).

Bandura in Widyastuti states that self-efficacy is an individual's belief that he is able to do something in certain situations successfully (Widyastuti, 2013). This self-efficacy also determines a person's success in finding solutions to his problems. In the world of work, self-efficacy is defined as a person's belief in his ability to direct motivation, cognitive resources and actions needed to succeed in carrying out his job (Rumantyeng \& Soehari, 2016). Self-efficacy is a self-confidence that directs a person to find solutions to a situation and is able to produce a positive attitude from the situation (Hamdi \& Abadi, 2014). In the world of education, teacher selfefficacy can have a positive effect on both the teacher and students (Adirestuty, 2017). Teachers who have high efficacy or selfconfidence will certainly have a positive impact on the environment in which they work. Efficacy is self-assessment, whether it can take good or bad actions, right or wrong, able or not able to do as required (Widyaninggar, 2015). Self-efficacy is a self-assessment where a person can determine whether he can meet the expectations of his goals or not. From several previous opinions, it can be concluded that self-efficacy is an individual's 
belief in the form of an assessment of himself regarding his ability to achieve goals.

Apart from self-efficacy, another factor that affects job stress is social support. This is because work stress will be minimized by the presence of social support from one's environment. Someone who experiences work stress will really need social support because social support can have a positive influence on employees where this social support will reduce work stress in the office (Indra Setiawan, 2013). This means that social support is indeed one of the factors that influence work stress, where if in a person's work environment there is high social support, then work stress is likely to be overcome. The same thing was conveyed by Rudianto and Murniati who argued that social support could reduce the negative effects of work stress which can affect individuals in meeting their job demands (Rudianto, 2019). Job demands are quite high in the teaching profession, which is a source of job stress. However, social support will make the teacher can meet the demands of the job that can reduce work stress. For employees, social support is needed so that work stress can be minimized (Khafidh, 2014). The same thing is applied to teachers where teacher work stress can be overcome with social support.

Social support is assistance obtained by an individual who comes from another person or group, whether in the form of material or nonmaterial, which can create a feeling of physical and psychological comfort for the individual concerned (Saputri \& Indrawati, 2011). This means that social support will create a comfortable feeling for those who receive it. Sarafino in Akbar and Tahoma conveyed the same thing that social support is a feeling of comfort, appreciation, attention, or assistance that an individual gets from another person or his group (Akbar \& Tahoma, 2018). Social support is also all general or specific supportive behavior given by people in an individual's social environment so that it can improve functioning or prevent individuals from various risks of loss (Rossallina \& Salim, 2019). This means that social support can be a solution to problems experienced by an individual. Sarafino and Smith in Aristya and Rahayu explain that social support can come from various sources such as parents, friends, lovers, and organizations or communities that are being lived by an individual (Aristya \& Rahayu, 2018). From some of these descriptions, it can be concluded that social support is any form of behavior that supports an individual to feel more comfortable and helps in the physical and psychological aspects of the person or group around him.

From some of the descriptions above, researchers are interested in examining problems related to job stress in teachers. Work stress, which has become an issue that often occurs for teachers, must, of course, be overcome because it can affect teacher performance which has an impact on the quality of learning that will be given later. Therefore, the right solution must be found to overcome this problem. By conducting this research, it is 
hoped that the problems related to teacher work stress can be resolved.

\section{RESEARCH HYPOTHESIS}

Based on the introduction that has been previously described, several hypotheses can be stated as follows: 1) Self-efficacy has a negative and significant effect on the work stress of civil servant teachers at Elementary School in Pondok Kelapa Village; 2) Social support has a negative and significant effect on work stress for civil servant teachers at Elementary School in Pondok Kelapa Village and 3) Self-efficacy and social support have a significant effect on work stress for civil servant teachers at Elementary School in Pondok Kelapa Village.

\section{METHOD}

This study uses a quantitative approach and multiple linear regression as the main model of research. The sampling technique in this research is a simple random sampling technique, in which the entire population will have the opportunity to be the research sample. This research was conducted at Elementary School in Pondok Kelapa Village. The study population was 101 civil servant teachers at Elementary School in Pondok Kelapa Village. After using the Slovin formula with an error rate of $5 \%, 81$ teachers were found to be the research samples. Data collection will be carried out using a closed questionnaire with a Likert scale of 1-5. The questionnaire is then applied using the google form application, where the teacher will be able to fill it out online.

Job stress will be the dependent variable $(Y)$, while self-efficacy and social support will be independent variables (X1 and $X 2$ ), respectively. Hypothesis testing in this study will use the t-test to partially determine the effect of the independent variable and the $F$ test to determine the effect of the independent variable simultaneously on the dependent variable. Meanwhile, as a prerequisite for analysis before performing multiple linear regression analysis, several test stages were carried out such as normality test, linearity test, multicollinearity test, and heteroscedasticity test. After all prerequisite test analysis is done, then the study will be followed by finding the equation of multiple linear regression model for this research as well as the coefficient of determination to see how influential independent variable on the dependent variable is.

Before the research was conducted, the validity and reliability of the research instrument were tested. Of the 35 statement items available from each variable, the following results were obtained for the validity test of the instrument ( $r>0.4438)$ : 1) The instrument for the work stress variable $(Y)$, which amounted to 35 statements, experienced a drop of 7 statements so that for the final instrument 28 statements will be distributed;2) The 
instrument for the self-efficacy variable (X1), which amounted to 35 statements, experienced a drop of 9 statements so that the final instrument to be distributed was 26 statements; 3) The instrument for the social support variable (X2), which amounted to 35 statements, experienced a drop of 8 statements so that the final instrument to be distributed was 27 statements. After the validity of the instrument, then the reliability test was carried out with the Spearman-Brown formula for each instrument which produced the following results: 1) The instrument for the work stress variable $(Y)$ had a reliability of 0.97 and could be categorized as having high reliability; 2) The instrument for the self-efficacy variable (X1) has a reliability of 0.78 and can be categorized as having moderate reliability and 3 ) The instrument for the social support variable (X2) has a reliability of 0.93 and can be categorized as having high reliability. This study uses SPSS version 25 software as a tool to help to complete the calculation of statistics.

\section{RESULTS}

After obtaining data related to the variables studied, the first analysis prerequisite test was carried out, namely the normality test. The normality test is carried out to find out whether the research data are normally distributed or not. A good regression model is a model whose research data are normally distributed. After the normality test was carried out with the Kolmogorov-Smirnov formula using SPSS version 25 on the variables of work stress $(\mathrm{Y})$, self-efficacy (X1), and social support (X2), the following results were obtained:

Table 1.The results of the Kolmogorov-Smirnov Normality Test using SPSS version 25

\begin{tabular}{lll}
\hline & & $\begin{array}{c}\text { Unstandardized } \\
\text { Residual }\end{array}$ \\
\hline $\mathrm{N}$ & & 81 \\
Normal Parameters & Mean & 0.000 \\
& Std. Deviation & 6.718 \\
Most Extreme Differences & Absolute & 0.093 \\
& Positive & 0.093 \\
& Negative & -0.056 \\
Statistical Test & & 0.093 \\
Asymp. Sig. (2-tailed) & & 0.078 \\
\hline
\end{tabular}

Conclusions can be drawn by looking at the value of Asymp.Sig. (2tailed) with the terms Asymp.Sig. (2-tailed) must be higher ( $>$ ) than 0.05. Because the results obtained show that the Asymp.Sig. (2tailed), namely $0.078>0.05$, it can be concluded that the data in this study were normally distributed.

After that, it was continued with the next prerequisite test, namely the linearity test. Linearity test is a test that finds out whether there is a linear 
relationship between each independent variable and the dependent variable. After calculating with the help of SPSS version 25, the following results were obtained:

Table 2. Test Results The linearity of self-efficacy variable (X1) to work stress variable (Y) by using SPSS version 25

\begin{tabular}{|c|c|c|c|c|c|c|}
\hline & & $\begin{array}{c}\text { Sum of } \\
\text { Squares }\end{array}$ & Df & $\begin{array}{l}\text { Mean } \\
\text { Square }\end{array}$ & $\mathbf{F}$ & Sig. \\
\hline \multirow{3}{*}{$\begin{array}{l}\text { Between } \\
\text { Groups }\end{array}$} & (Combined) & 6137.586 & 38 & 161.515 & 2.409 & 0.003 \\
\hline & Liniearity & 4266.252 & 1 & 4266.252 & 63.625 & 0.000 \\
\hline & $\begin{array}{l}\text { Deviation from } \\
\text { Linearity }\end{array}$ & 1871.334 & 37 & 50.577 & 0.754 & 0.807 \\
\hline $\begin{array}{l}\text { Within } \\
\text { Groups }\end{array}$ & & 2816.217 & 42 & 67.053 & & \\
\hline Total & & 8953.802 & 80 & & & \\
\hline
\end{tabular}

From the data above, it can be seen whether there is a linear relationship between the self-efficacy variable $(\mathrm{X} 1)$ and the work stress variable $(\mathrm{Y})$ by looking at the Deviation from Linearity value. If the Deviation from Linearity value $>0.05$, it can be concluded that there is a linear relationship between the self-efficacy variable $(\mathrm{X} 1)$ and the work stress variable $(\mathrm{Y})$. Since the Deviation from Linearity value from the results above is $0.807>0.05$, it can be concluded that there is a linear relationship between the self-efficacy variable $(\mathrm{X} 1)$ and the work stress variable $(\mathrm{Y})$.

Table 3. Test Results The linearity of social support variables (X2) on work stress variable $(Y)$ by using SPSS version 25

\begin{tabular}{lllllll}
\hline & & $\begin{array}{c}\text { Sum of } \\
\text { Squares }\end{array}$ & Df & $\begin{array}{c}\text { Mean } \\
\text { Square }\end{array}$ & F & Sig. \\
\hline $\begin{array}{l}\text { Between } \\
\text { Groups }\end{array}$ & (Combined) & 4842.869 & 32 & 151.340 & 1.767 & 0.036 \\
& & & & & \\
& $\begin{array}{l}\text { Liniearity } \\
\text { Deviation from }\end{array}$ & 2763.569 & 1 & 276.569 & 32.268 & 0.000 \\
& Linearity & 2079.300 & 31 & 67.074 & 0.783 & 0.763 \\
Within & & 4110.933 & 48 & 85.644 & & \\
Groups & & & & & & \\
Total & & 8953.802 & 80 & & & \\
\hline
\end{tabular}

From the data above, it can be seen whether there is a linear relationship between the social support variable $(\mathrm{X} 2)$ and the work stress variable $(\mathrm{Y})$ by looking at the Deviation from Linearity value. If the value of Deviation from Linearity $>0.05$, it can be concluded that there is a linear relationship 183 | Akademika | Vol 9 | No. 2 | 2020 
between social support variables (X2) and work stress variables $(Y)$. Because the Deviation from Linearity value from the above results is $0.763>0.05$, it can be concluded that there is a linear relationship between the social support variable $(\mathrm{X} 2)$ and the work stress variable $(\mathrm{Y})$.

The next step is to conduct a multicollinearity test as one of the prerequisites for analysis in multiple linear regression. The multicollinearity test aims to find out whether there is a multicollinearity problem in this study, namely where there is a relationship between the independent variables. $A$ good regression model is a model that does not have multicollinearity problems.

Table 4. Multicollinearity test results using SPSS version 25

\begin{tabular}{lll}
\hline & $\begin{array}{c}\text { Collinearity } \\
\text { Tolerance }\end{array}$ & $\begin{array}{c}\text { Statistic } \\
\mathbf{s} \text { VIF }\end{array}$ \\
\hline (Constant) & & \\
Self Efficacy & 0.891 & 1.123 \\
Social Support & 0.891 & 1.123 \\
\hline
\end{tabular}

Decision making on the multicollinearity test is based on the tolerance value and VIF. If the tolerance value is $>0.10$, it can be concluded that there is no multicollinearity problem in this study. Because the tolerance value for the variable self-efficacy (X1) and social support $(\mathrm{X} 2)$ is 0.891 which is higher than $(>) 0.10$, it can be concluded that there is no multicollinearity problem in this regression model. In addition, decisions can also be made by looking at the VIF value on the condition that if the VIF value is $<10.00$, there is no multicollinearity problem. Since the VIF value for the independent variable in this study is $1.123<10.00$, it can be concluded that there is no multicollinearity problem in this regression model.

After the multicollinearity test, the final step is to take the prerequisite test for multiple linear regression analyses, namely the heteroscedasticity test. A heteroscedasticity test is a test that aims to test whether, in a regression model, there is an inequality of variance from the residuals of one observation to another. A good regression model is a regression model that does not have a heteroscedasticity problem. The heteroscedasticity test in this study used the Glesjer test. By calculating using SPSS version 25 , the following results were obtained for the heteroscedasticity test : 
Table 5. Heteroscedasticity test results using SPSS version 25

\begin{tabular}{llllll}
\hline \multicolumn{1}{c}{ Variable } & \multicolumn{2}{c}{$\begin{array}{c}\text { Unstandardized } \\
\text { Coefficients }\end{array}$} & $\begin{array}{c}\text { Standardized } \\
\text { Coefficients } \\
\text { Beta }\end{array}$ & t & Sig. \\
\hline B Constant) & 6.835 & 7.053 & & & \\
Self Efficacy (X1) & -0.085 & 0.048 & -0.208 & -1.769 & 0.081 \\
Social Support (X2) & 0.059 & 0.062 & 0.112 & 0.950 & 0.345 \\
\hline
\end{tabular}

Dependent Variable: Abs_RES

Decisions in the heteroscedasticity test with the Glesjer test can be taken by looking at the significance value. The condition that must be fulfilled is that the significance value must be higher than $(>)$ 0.05. By looking at the results above, it is known that the significance value (Sig.) of the selfefficacy variable (X1) is 0.081 , and the significance value (Sig.) of the social support variable $(\mathrm{X} 2)$ is 0.345 . Because the two variable significance values are higher $(>)$ than 0.05 , it can be concluded that there is no heteroscedasticity problem in this regression model.

After all the analysis prerequisites for the multiple linear regression model have been fulfilled, a test will be carried out to find out the multiple linear regression model in this study. After calculating using SPSS version 25, the following results were obtained:

Table 6.Multiple Linear Regression Test Results using SPSS version 25

\begin{tabular}{|c|c|c|c|c|c|}
\hline \multirow{2}{*}{ Variable } & \multicolumn{2}{|c|}{$\begin{array}{l}\text { Unstandardized } \\
\text { Coefficients }\end{array}$} & \multirow{2}{*}{$\begin{array}{c}\text { Standardized } \\
\text { Coefficients } \\
\text { Beta }\end{array}$} & \multirow{2}{*}{$t$} & \multirow{2}{*}{ Sig. } \\
\hline & B & Std. Error & & & \\
\hline (Constant) & 148.627 & 10.596 & & 14.026 & 0.000 \\
\hline Self Efficacy (X1) & -0.537 & 0.072 & -0.569 & -7.464 & 0.000 \\
\hline Social Support (X2) & -0.452 & 0.094 & -0.367 & -4.823 & 0.000 \\
\hline
\end{tabular}

From the results above, it can be seen that the regression model for this study is as follows: $Y=148.627-0.537-0.452$. From these results, several things can be interpreted as follows:

1. The value of the regression coefficient for the self-efficacy variable $(X 1)$ is -0.537 which explains that if the social support variable $(X 2)$ is zero, then self-efficacy $(\mathrm{X} 1)$ will affect work stress $(\mathrm{Y})$ by -0.537 . 
2. The value of the regression coefficient for the social support variable $(X 2)$ is -0.452 which explains that if the self-efficacy variable $(\mathrm{X} 1)$ is zero, then social support $(\mathrm{X} 2)$ will affect work stress $(\mathrm{Y})$ by 0.452 .

Then, also obtained the coefficient of determination for this study which is shown in the table as follows:

Table 7.The value of the coefficient of determination using SPSS version 25

\begin{tabular}{cccl}
\hline R & R Square & Adjusted R Square & $\begin{array}{l}\text { Std. Error of } \\
\text { the Estimate }\end{array}$ \\
\hline 0.772 & 0.597 & 0.586 & 6.804 \\
\hline
\end{tabular}

From the results obtained, it can be seen the coefficient of determination from this regression equation. The coefficient of determination is a quantity value that show how much independent variable $(X)$ simultaneously made effect to the dependent variable $(\mathrm{Y})$. From the results obtained, it is known that the coefficient of determination is 0.597 or $59.7 \%$, which means that the variables of self-efficacy $(\mathrm{X} 1)$ and social support (X2) together have an influence on the work stress variable $(Y)$ of $59.7 \%$. Meanwhile, the other $40.3 \%$ are influenced by other variables that are not researched.

To find out the truth of the research hypothesis that has been previously presented, a hypothesis test will be carried out using the t-test and $\mathrm{F}$ test. The t-test is carried out to find out how much the influence of the independent variable partially exerts on the dependent variable. After calculating using SPSS version 25, the following results are obtained for the t-test :

Table 8. T-test using SPSS version 25

\begin{tabular}{lcc}
\hline \multicolumn{1}{c}{ Variable } & T & Sig. \\
& & \\
\hline (Constant) & 14.026 & 0.000 \\
Self Efficacy (X1) & -7.464 & 0.000 \\
Social Support (X2) & -4.823 & 0.000 \\
\hline
\end{tabular}

From the results above, it can be seen how partially the influence of the independent variables on the dependent variable. Conclusions can be drawn by looking at the value of $t$ count and the significance of each variable.

By looking at $t$ count, the hypothesis is accepted if $t$ value $>t$ table. By 
looking at the table of calculation results obtained, the t value for the selfefficacy variable is 7.464 (negative indicates the area of negative influence). Because $t$ is 7.464 higher $(>)$ than $t(78)$ table are worth 1.99 , it can be concluded that self-efficacy significantly and negatively related to job stress. Conclusions can also be drawn by paying attention to the significant value provided that if the significance value is $<0.05$, the hypothesis is accepted. Due to the significant value of self-efficacy variable (X1) that is equal to 0.00 lower $(<)$ than 0.05 , it can be concluded that the first hypothesis is accepted, which means self-efficacy has a negative and significantly effect on the work stress of civil servant teachers at Elementary School in Pondok Kelapa Village.

The same thing was done for the social support variable (X2). By looking at the calculated value, it can be determined whether this research hypothesis is accepted or not. Because the $t$ value is 4.823 (negative indicates the area of negative influence) which is higher (>) than the $t(78)$ table and has a value of 1.99 , it can be concluded that social support has a negative and significant effect on work stress. The same thing can also be seen by looking at the significance value of the social support variable. Due to the significant value of social support is at 0.00 lower $(<)$ than 0.05 , then the second hypothesis can be accepted, which means that social support has a negative and significant effect on the work stress of civil servant teachers at Elementary School in Pondok Kelapa Village.

After the t-test was carried out to find out the effect of the independent variables partially, the $F$ test was carried out to determine the effect of the independent variables simultaneously. The $\mathrm{F}$ test in this study was carried out using SPSS version 25. The results of the $F$ test can be seen through the Anova table. After the statistical calculation, the result is as follows:

Table 9. F-test using SPSS version 25

\begin{tabular}{llllll}
\hline \multicolumn{1}{c}{ Model } & \multicolumn{1}{c}{$\begin{array}{c}\text { Sum of } \\
\text { Squares }\end{array}$} & Df & \multicolumn{1}{c}{$\begin{array}{c}\text { Mean } \\
\text { Square }\end{array}$} & F & Sig. \\
\hline Regression & 5342.910 & 2 & 2671.455 & 57.707 & 0.000 \\
Residual & 3610.892 & 78 & 46.293 & & \\
Total & 8953.802 & 80 & & & \\
\hline
\end{tabular}

The results of the $F$ test can be seen by looking at the calculated $F$ value and significance. By looking at the calculated $F$ value, the conditions that must be met in order for the hypothesis to be accepted are $F$ count $>F$ table. From the table above, it is known that the calculated $F$ value is 57.707. Because the calculated $F$ value of 57.707 is higher than the $F(2$, 79) table which is 3.11 , it can be concluded that self-efficacy and social support simultaneously affect work stress. In addition, conclusions can be drawn by looking at the significance value. The conditions that must be met 187 | Akademika | Vol 9 | No. 2 | 2020 
in order for the hypothesis to be accepted are a significance value $>0.05$. Because the significant value gained is 0.00 higher $(<)$ than 0.05 , the third hypothesis is accepted. This means that self-efficacy and social support simultaneously have an influence on the work stress of civil servant teachers at Elementary School in Pondok Kelapa Village.

\section{DISCUSSION}

\section{THE EFFECT OF SELF-EFFICACY ON WORK STRESS}

After seeing the results of the t-test, it is known that the first hypothesis is accepted, which means that self-efficacy has a negative and significant effect on the work stress of civil servant teachers at Elementary School in Pondok Kelapa Village. It can be seen from the significant value that is 0.00 lower $(<)$ than 0.05 . In addition, $t$ value that is equal to 7.464 higher $(>)$ than $t$ (78) tables is worth 1.99, which also shows the first hypothesis is accepted. This means that there is indeed a negative and significant effect provided by self-efficacy on work stress. This means the higher selfefficacy, the stress of work will be lower.

This is similar to the research conducted by Sari and Handayani with the title of research on the Relationship of Self Efficacy and Work Stress in Semarang State School Teachers. The results of Sari's research show that self-efficacy and work stress have a negative and significant relationship with a determination coefficient of $32.1 \%$ (Sari \& Handayani, 2017). This means that the higher the self-efficacy of a teacher, the more he will avoid work stress. This high self-efficacy can reduce work stress because teachers who have high self-efficacy will have the confidence to overcome various kinds of problems in their work. High self-efficacy can also influence teachers to create the perception that they can carry out their work without problems.

The results of this study are also similar to the research conducted by Prahara and Indriani with a study entitled Employees: Occupational SelfEfficacy and Work Stress. This research conducted by Indriani shows that there is a negative and significant relationship between self-efficacy and work stress (Prahara \& Indriani, 2019). Similar research conducted by Sumitro et.al. with the title Correlation Between Self Efficacy to Job Stress of Sales Operation Employee's PT. Nasmoco Group Semarang. The results of this study also showed a negative and significant relationship with a determination value of $22 \%$ between self-efficacy and work stress. This means that high self-efficacy will reduce stress on a person.

Self-efficacy in teachers is not only an existing thing but also must be familiarized with a teacher. Teachers who are confident in their abilities, not only can cope with work stress but also can produce maximum performance in their work. With high efficacy, teachers will have a positive impact on their 
work environment. Teachers who have self-efficacy may have a positive impact on students, which will affect their learning outcomes for the better. In addition, self-efficacy in a teacher is also very important because of his considerable responsibilities at work. This responsibility will not feel heavy when the teacher is sure that he can complete his assignments. In addition, teachers who have high self-efficacy will also be able to face problems with the best solutions for themselves.

\section{THE EFFECT OF SOCIAL SUPPORT ON WORK STRESS}

Through t-test, it is known that the second hypothesis is accepted, in which the means of social support significantly and negatively related to job stress on elementary school civil servant teachers in the village of Pondok Kelapa. It can be seen from the significant value that is 0.00 lower $(<)$ than 0.05 . In addition, the $t$ value is 4.823 which is higher $(>)$ than the $t(78)$ table and has a value of 1.99 , also shows that the first hypothesis is accepted. This means that there is indeed a negative and significant effect provided by social support on work stress. This means that the higher the social support, the lower work stress will be.

Research conducted by Setiawan revealed a similar thing in which the results of research on 30 research subjects showed that social support had a significant effect on work stress for the employees of UPT PSAWS Bengawan Solo Bojonegoro (Indra Setiawan, 2013). Research conducted by Riyadi and Sarsono also showed that social support has a significant relationship (Riyadi \& Sarsono, 2019). The research entitled The Effect of Colleague Social Support and Internal Locus of Control on Nurse Work Stress also suggests that the higher the social support received, the lower the existing work stress, and vice versa. This shows that social support is also a way to deal with work stress in someone.

Teachers, as a profession that is prone to work stress, need a variety of ways to overcome it. Social support is one of the things that can reduce work stress. Social support from colleagues is one of them. Supportive coworkers will certainly be able to help teachers through problems in their work. Helping each other at work will reduce the workload of a teacher which can also avoid work stress. Not only direct support but also moral support is very important, and it is that work stress affects a teacher not only physically but also psychologically. Moral, social support from the closest people will help teachers to avoid stress and also reduce it if there is one. Therefore, it is very important in the school environment to create a supportive environment. In addition, support from family or partners may also help teachers reduce work stress. 


\section{THE EFFECT OF SELF-EFFICACY AND SOCIAL SUPPORT ON WORK STRESS}

Through the F-test, it is known that the third hypothesis is also accepted. This can be found through the calculated $F$ value and significance. By looking at the calculated $F$ value, it obtained 57.707 which is higher $(>)$ than $F$ table for 3.11. So it can be concluded that self-efficacy and social support simultaneously influence the work stress of civil servant teachers at Elementary School in Pondok Kelapa Village. This hypothesis can also be proven by looking at the significance value of the $F$ test of 0.000 which is lower $(<)$ than 0.05 , which indicates that the research hypothesis is indeed acceptable. This means that self-efficacy and social support can affect the level of work stress on teachers.

From the existing regression model, the coefficient of determination is also found to be 0.597 or $59.7 \%$, which means that the variable selfefficacy (X1) and social support (X2) simultaneously have an influence on the work stress variable $(Y)$ of $59.7 \%$. Meanwhile, the other $40.3 \%$ are influenced by other variables that are not researched. This means that these two variables have a considerable influence on work stress on civil servant teachers at Elementary School in Pondok Kelapa Village.

\section{RESEARCH LIMITATIONS}

Because this research was conducted during a pandemic, there are many deficiencies in it. One of them is sampling using a $5 \%$ error rate. This causes the samples taken only amounted to 81 people from 101 people. Perhaps this sample size can also reduce the accuracy of the data in the study. Therefore, if there are other studies that wish to discuss similar matters, it is hoped that they can obtain a much larger number of samples. In addition, if you want to discuss the same problem related to work stress, you may take different independent variables because there may be other factors that influence it.

\section{CONCLUSION}

Based on the analysis that has been done, the following conclusions can be concluded: 1) Self-efficacy has a negative and significant effect on the work stress of civil servant teachers at Elementary School in Pondok Kelapa Village; 2) Social support has a negative and significant effect on the work stress of civil servant teachers at Elementary School in Pondok Kelapa Village and 3) Self-efficacy and social support simultaneously have a significant effect on work stress for civil servant teachers at Elementary School in Pondok Kelapa Village.

Based on the conclusions above, it can be seen that job stress is influenced by self-efficacy and social support. This means that self-efficacy and social support are factors that significantly influence job stress. By 
increasing the self-efficacy of a teacher, it is likely that the teacher will avoid work stress. Self-efficacy in teachers is not only an existing thing, it must also be familiarized with a teacher. Teachers who are confident in their own abilities can not only cope with work stress, but also can produce maximum performance in carrying out their jobs. With high self-efficacy for teachers, it will have a positive impact on the work environment. Meanwhile, social support for teachers is an important factor to reduce work stress. Social support can come from the leader (the principal), colleagues, family and people around the teacher. Colleagues who provide social support will certainly be able to help teachers through problems in their work; and helping each other at work, will reduce the workload of a teacher which can also avoid work stress.

\section{REFERENCES}

Adirestuty, F. (2017). Pengaruh Self-Efficacy Guru dan Kreativitas Guru Terhadap Motivasi Belajar Siswa dan Implikasinya Terhadap Prestasi Belajar Pada Mata Pelajaran Ekonomi. Jurnal Wahana Pendidikan.

Akbar, Z., \& Tahoma, O. (2018). Dukungan Sosial dan Resilensi Diri Pada Guru Sekolah Dasar. JPPP - Jurnal Penelitian Dan Pengukuran Psikologi. https://doi.org/10.21009/jppp.071.07

Aristya, D. N., \& Rahayu, A. (2018). Hubungan Dukungan Sosial dan Konsep Diri Dengan Penyesuaian Diri Remaja Kelas X SMA Angkasa I Jakarta. Jurnal Humaniora.

Efendi, R. (2013). Self efficacy: studi idigenous pada guru bersuku jawa. Journal of Social and Industrial Psychology.

Hamdi, S., \& Abadi, A. M. (2014). Pengaruh Motivasi, Self-Efficacy dan Latar Belakang Pendidikan Terhadap Prestasi Matematika Mahasiswa PGSD STKIP-H DAN PGMI IAIH. Jurnal Riset Pendidikan Matematika. https://doi.org/10.21831/jrpm.v1i1.2666

Indra Setiawan, A. (2013). Pengaruh Dukungan Sosial Terhadap Stres Kerja Pada Karyawan. Character: Jurnal Penelitian Psikologi.

Khafidh, A. D. (2014). Hubungan Antara Dukungan Sosial Dengan Stres Kerja Pada Karyawan Solopos. Jurnal KESMAS.

Kusnadi, M. A. (2014). Hubungan antara beban kerja dan self-efficacy dengan stres kerja pada dosen Universitas X. Calyptra: Jurnal Ilmiah Mahasiswa Universitas Surabaya.

Paramita, L., \& Sendow, G. (2016). Pengaruh Komunikasi Organisasi dan Stres Kerja Terhadap Kepuasan Kerja Serta Dampaknya Terhadap Kinerja Karyawan di Perusahaan Umum Bulog Divisi Regional Sulawesi Utara. Jurnal Riset Ekonomi, Manajemen, Bisnis Dan Akuntansi. https://doi.org/10.35794/emba.v4i1.11580

191 | Akademika | Vol 9 | No. 2 | 2020 
Prahara, S. A., \& Indriani, N. (2019). Employees: Occupational Self-Efficacy and Work Stress. Journal Of Psychology and Instruction, 3(3), 91-96.

Putranto, C. (2013). Faktor - Faktor Yang Mempengaruhi Stres Kerja : Studi Indigenous Pada Guru Bersuku Jawa. Journal of Sosial and Industrial Psychology.

Riyadi, R. S., \& Sarsono, S. (2019). Pengaruh dukungan sosial rekan kerja dan locus of control internal terhadap stres kerja perawat. Journal of Health Studies. https://doi.org/10.31101/jhes.726

Rossallina, L., \& Salim, R. A. (2019). Perilaku eksplorasi karier, dukungan sosial, dan keyakinan dalam pengambilan keputusan karier SMP. Persona:Jurnal Psikologi Indonesia. https://doi.org/10.30996/persona.v8i2.2627

Rudianto, B. R. A. (2019). Komunikasi Organisasi, Stres Kerja dan Kinerja Karyawan: Dukungan Sosial Sebagai Variabel Moderasi. Jurnal Akuntansi Bisnis. https://doi.org/10.24167/jab.v17i1.2291

Rumantyeng, O. D., \& Soehari, T. D. (2016). Pengaruh Kecerdasan Emosional, Self Efficacy dan Kepuasan Kerja terhadap Kinerja Guru SMA Negeri 13 Tanggerang. Akademika : Jurnal Teknologi Pendidikan, 5(1), 119-138.

Saputri, M. W., \& Indrawati, E. S. (2011, April). Hubungan Antara Dukungan Sosial dengan Depresi pada Lanjut Usia yang Tinggal di Panti Wreda Wening Wardoyo Jawa Tengah. Jurnal Psikologi Undip, 9(1), 65-72.

Sari, R. P., \& Handayani, A. (2017). Hubungan Efikasi Diri dan Stres Kerja Pada Guru Sekolah Luar Biasa Negeri Semarang. Proyeksi.

Stres Kerja. (2015). Buletin Psikologi. https://doi.org/10.22146/bpsi.7406

Steven, W., \& Sahrah, A. (2019). Pengaruh Kecerdasan Emosi dan Efikasi Diri Terhadap Stres Kerja pada Karyawan NU IMEJ Agency And Event Organizer Yogyakarta. Prosiding Seminar Nasional Pakar Ke 2 Tahun 2019 (pp. 2.6.1-2.6.6). Jakarta: Lembaga Penelitian Universitas Trisakti.

Triana, K., Rahmi, T., \& Putra, Y. Y. (2015). Kontribusi Persepsi pada Beban Kerja dan Kecerdasan Emosi terhadap Stres Kerja Guru SMP yang Tersertifikasi. Jurnal Ilmiah Psikologi Terapan.

Wahdaniyah, N., \& Miftahuddin, M. (2019). Pengaruh Hardiness, Beban Kerja, dan Faktor Demografi Terhadap Stres Kerja Guru. TAZKIYA JOURNAL OF PSYCHOLOGY. https://doi.org/10.15408/tazkiya.v6i1.11010

Wartono, T. (2017). Pengaruh Stres Kerja Terhadap Kinerja Karyawan : Studi Kasus pada Karyawan Majalah Mother and Baby. Jurnal Ilmiah Prodi Manajemen Universitas Pamulang.

Widyaninggar, A. A. (2015). Pengaruh Efikasi Diri dan Lokus Kendali (Locus of Control) Terhadap Prestasi Belajar Matematika. Formatif: Jurnal Ilmiah Pendidikan MIPA. https://doi.org/10.30998/formatif.v4i2.143

Widyastuti, R. J. (2013). Pengaruh self-efficacy dan dukungan sosial keluarga terhadap kemantapan pengambilan keputusan karir siswa. Jurnal BK UNESA. 
Yana, D. (2014). Stres Kerja pada Perawat Instalasi Gawat Darurat di RSUD Pasar Rebo Tahun 2014. Jurnal Administrasi Rumah Sakit Indonesia. 